\title{
PATTERNS OF LOW BIRTH WEIGHT IN WEST JERUSALEM WITH SPECIAL REFERENCE TO MATERNAL ORIGIN
}

SUSAN LEGG, M.B., B.S. Research Assistant

A. MICHAEL DAVIES, M.D. Professor

RACHEL PRYWES, R.N., Dip.Obst. Chief Nurse

VELIMIR V. STERK, M.D. Lecturer

PEARL WEISKOPF, B.Sc. Statistician

Department of Medical Ecology, Hebrew University-Hadassah Medical School, Jerusalem, Israel

THE importance of low birth weight for survival and development and its relationships to gestation period, parity, maternal age, race, social class, nutrition, height and physique, smoking, and many other factors are the subject of continuing research, the goal being prevention of death and damage in early life (Butler and Alberman, 1969; Shapiro, Schlesinger, and Nesbitt, 1968; Abramovicz and Kass, 1966; Rantakallio, 1969).

One of the problems in studying the influence of race and social class on this aspect of health is the difficulty in separating the effects of poverty from those of genetic factors. Baird (1962), Baird and Illsley (1953), and Thomson and Billewicz (1963) have suggested that rates of low birth weight, among other aspects of suboptimal pregnancy outcome, are higher in low social classes not only because of poor nutrition and health during pregnancy, but also because such women have suffered an unfavourable environment throughout their early life and in particular during their growing period. It is easy to accept that poverty and malnutrition in childhood will stunt growth and may be associated with suboptimal pelvic shape (and consequent increase in caesarian section and perinatal death rates), but their relationship to low birth weight in the next generation is less clear, saving a Lamarkian view. A poor environment in the past should not affect a woman's ability to produce a child of normal birth weight, providing her present state of health and nutrition were adequate. Such a hypothesis would be almost impossible to test in large numbers in western countries where social class is often life long, and upward or downward social mobility may be associated with a process of genetic selection, linked to, among other things, maternal height, intelligence, and many aspects of pregnancy outcome (Thomson, 1959). The situation in Jerusalem, on the other hand, provides an unusual opportunity to study this problem in a heterogeneous population of mothers whose early lives were spent in widely differing economic circumstances but whose offspring show indices of perinatal health that compare favourably with those of Britain and the U.S.A.

This paper presents an analysis of some demographic and socio-ethnic attributes of women who delivered underweight babies in Jerusalem in 1964-67. The data were collected prospectively and are part of the on-going Jerusalem Perinatal Study (Davies, Prywes, Tzur, Weiskopf, and Sterk, 1969).

\section{Material ANd Methods}

The study population consists of all live and stillborn singleton infants born in West Jerusalem to local residents whose pregnancies had lasted 28 weeks or longer. The period covered by the study is 1 April 1964 to 31 December 1967 inclusive, the first three months of 1964, the 'running in' period of the Jerusalem Perinatal Study, being excluded as 
stillbirth data had been collected retrospectively and were less complete.

The design and demographic base of the Jerusalem Perinatal Study have been described in detail by Davies and his colleagues (Davies, Tzur, Prywes, and Weiskopf, 1968; Davies et al., 1969). In brief, the study was set up in 1964 to include the outcome of all pregnancies in the West Jerusalem population, i.e., that of Jerusalem, Israel, before June 1967. Demographic data and details of maternal health during pregnancy and delivery, as well as details of infant malformations, admissions to hospital, and deaths, are linked by computer matching of the records derived from birth and death certificates, interviews with the pregnant women, and reports from hospitals and Mother and Child Health Clinics. Obstetric services are free, all deliveries are in hospital, and more than $99.7 \%$ of the mothers have medically supervised antenatal care.

\section{Special Characteristics of Population}

(1) Two-thirds of the mothers are immigrants, the majority having spent their early life and growing period under conditions ranging from moderate to extreme poverty which was not completely alleviated until some years after their arrival in Israel. The immigrants came from countries of North Africa, Asia (mainly the Near East), and western countries, including both survivors of the Nazi holocaust and immigrants from the Americas and English-speaking countries (Eliner, 1968). Over one-half of the Israeli-born mothers are of European origin and one-quarter are second or more generation of native born: their early environmental experience, while not always comfortable, was not associated with malnutrition.

(2) The population includes a high proportion of grand multiparae and of illiterate or semi-literate mothers for whom obstetric services and data are no less complete than for the other women. Fifteen percent of Jerusalem mothers in 1964-69 were having their seventh or subsequent baby, the figure being $23 \%$ for immigrants from Asia and North Africa but only $7 \%$ for Israeli-born mothers and immigrants from western countries. Fourteen percent of all the mothers had had no formal schooling and $20 \%$ had had less than five years. Of immigrant mothers from Asia and North Africa, $39 \%$ had had less than five years of schooling.

(3) There is less social stratification than in western countries. Factors such as occupation, income, education, housing, length of time since immigration, army rank, and religious affiliation, which are usually well-defined associates of social class in western countries, do not correlate with each other in Israel and may have variable significance in different ethnic groups (Eisenstadt, 1967; Kark, Peritz, Shiloh, and Slome, 1964). Income differentials between the richest and poorest are small by western standards, and even the concept of social class in Israeli society is denied by many Israelis.

In the early years after their immigration to Israel, immigrants from Asia and North Africa were at an economic disadvantage, being largely illiterate and unskilled. With universal education and health services, the impact of this disadvantage on many health differentials between these immigrants and their Israeli-born or western counterparts is fast disappearing (Huppert, 1968; Central Bureau of Statistics (1952-69).

\section{Variables AND Methods of Analysis}

'Low birth weight' in this study is defined as a weight of less than $2,500 \mathrm{~g}$. This figure was chosen, rather than $2,501 \mathrm{~g}$., because of an observed tendency to rounding downwards to the nearest $50 \mathrm{~g}$. Infants whose weight was recorded as exactly $2,500 \mathrm{~g}$. were $0.7 \%$ of the total.

Apart from birthweight, the following four variables have been studied:

(1) ethnic group: defined by the place of birth ofô the mother;

(2) maternal age: obtained by subtracting the mother's year of birth from the year of delivery;

(3) total birth order: calculated from the total number of live and still-born infants ever born to the mother, twins counting as two. Previous abortions are not included;

(4) maternal education: or years of schooling. The recording of maternal education was incomplete, and for $17 \%$ of the births maternal education is unknown. Most of these unknowns represent illiterate mothers, but there may be additional biases. These unknowns are treated as a separate education rank in all the calculations.

Adjustments for variation in the distribution of maternal age, ethnic group, education, and birth order have been made by the indirect method, using the whole parturient population as a standard, and the results are expressed as ratios $\times 100$ of observed to index (expected) rates. Tests of significance of adjusted differences have been made by the methods of Mantel and Haenszel (1959), Van Elteren (1960), and Goodman (1964).

\section{Results}

There were 21,312 single births, 1,216 of the babies weighing less than $2,500 \mathrm{~g}$., an overall rate of $5.7 \%$.

Unknown weights amounted to $1 \cdot 1 \%$ with no 
TABLE I

LOW BIRTH WEIGHT BY ETHNIC GROUP, MATERNAL, AGE, BIRTH ORDER, AND EDUCATION

\begin{tabular}{|c|c|c|c|c|}
\hline Variable & $\begin{array}{c}\text { No. of Infants } \\
\text { wt }<2,500 \mathrm{~g} .\end{array}$ & $\begin{array}{c}\text { Crude Rate } \\
\%\end{array}$ & Adjusted Ratio* & p† \\
\hline $\begin{array}{l}\text { Ethnic group (based on birthplace of } \\
\text { mother) } \\
\text { Israel } \\
\text { Asia } \\
\text { North Africa } \\
\text { Western Countries } \\
\text { Non-Jews and Unknown }\end{array}$ & $\begin{array}{r}437 \\
350 \\
214 \\
166 \\
49\end{array}$ & $\begin{array}{l}5 \cdot 7 \\
6 \cdot 6 \\
4 \cdot 2 \\
6 \cdot 0 \\
8 \cdot 6\end{array}$ & $\begin{array}{l}104 \\
112 \\
72 \\
109 \\
-\end{array}$ & $\begin{array}{c}\text { n.s. } \\
\text { n.s. } \\
<0.0001 \\
\text { n.s. }\end{array}$ \\
\hline $\begin{array}{l}\text { Maternal age } \\
24 \text { or less } \\
25-29 \\
30-34 \\
35 \text { or more } \\
\text { Unknown }\end{array}$ & $\begin{array}{r}410 \\
362 \\
238 \\
195 \\
11\end{array}$ & $\begin{array}{r}5.9 \\
5.6 \\
5.0 \\
6.3 \\
17.2\end{array}$ & $\begin{array}{r}91 \\
98 \\
95 \\
124 \\
-\end{array}$ & $\begin{array}{c}\text { n.s. } \\
\text { n.s. } \\
\text { n.s. } \\
<0.001\end{array}$ \\
\hline $\begin{array}{l}\text { Birth order } \\
\quad 1-3 \\
2-3 \\
4-6 \\
7 \text { or more } \\
\text { Unknown } \\
\end{array}$ & $\begin{array}{r}407 \\
434 \\
223 \\
144 \\
8\end{array}$ & $\begin{array}{r}7.1 \\
5.4 \\
4.9 \\
4.8 \\
14.8\end{array}$ & $\left.\begin{array}{c}124 \\
96 \\
87 \\
79 \\
-\end{array}\right\}$ & $\begin{array}{r}<0.00001 \\
<0.00001 \\
<0.01\end{array}$ \\
\hline $\begin{array}{l}\text { Education (years of schooling) } \\
13 \text { or more } \\
9-12 \\
5-8 \\
0-4 \\
\text { Unknown }\end{array}$ & $\begin{array}{l}165 \\
263 \\
301 \\
202 \\
285\end{array}$ & $\begin{array}{l}5 \cdot 0 \\
5 \cdot 0 \\
5 \cdot 3 \\
5 \cdot 7 \\
8 \cdot 8\end{array}$ & $\left.\begin{array}{r}79 \\
87 \\
93 \\
111 \\
128\end{array}\right\}$ & $<0.00001$ \\
\hline Total & 1,216 & 5.7 & 100 & \\
\hline
\end{tabular}

*Adjusted, in each case, for the other three variables †Adjusted differences

significant variation by maternal age or birth order and only a small excess $(2.3 \%)$ in the unknown education group. Between the four Jewish ethnic subgroups there were no significant differences, but in non-Jews (mainly Arabs) unknown weights were $8.7 \%$. Non-Jews have therefore been grouped with Jews of unknown origin and, although included in the totals, they are not studied as a separate group.

Table I shows numbers and crude rates of low birth weight by maternal age, birth order, ethnic group, and education, together with ratios adjusted in each case for the other three variables. Tables II to VII show cross tabulations for each of the six combinations of pairs of variables.

\section{ETHNIC GROUP}

North African immigrant mothers, with $4.2 \%$ of low birth weight among their offspring, have the lowest crude rate and immigrants from Asia, with $6.6 \%$, the highest (Table I). The Israeli-born and

TABLE II

LOW BIRTH WEIGHT BY ETHNIC GROUP AND MATERNAL AGE (Ratios adjusted for birth order and education)

\begin{tabular}{|c|c|c|c|c|c|c|}
\hline \multirow{2}{*}{\multicolumn{2}{|c|}{$\begin{array}{l}\text { Birthplace of } \\
\text { Mother }\end{array}$}} & \multicolumn{3}{|c|}{ Age of Mother (yr.) } & \multirow{2}{*}{$\begin{array}{l}\text { Total } \\
\text { (including unknowns) }\end{array}$} & \multirow{2}{*}{$\begin{array}{c}\text { Significance of } \\
\text { Adjusted Maternal } \\
\text { Age-effect }\end{array}$} \\
\hline & & $<24$ & $25-34$ & $35+$ & & \\
\hline Israel & $\begin{array}{l}\text { No. } \\
\text { Crude rate \% } \\
\text { Adjusted ratio }\end{array}$ & $\begin{array}{l}155 \\
6 \cdot 1 \\
96\end{array}$ & $\begin{array}{r}237 \\
5.4 \\
104\end{array}$ & $\begin{array}{r}44 \\
6 \cdot 1 \\
133\end{array}$ & $\begin{array}{r}437 \\
5.7 \\
104\end{array}$ & 0.001 \\
\hline Asia & $\begin{array}{l}\text { No. } \\
\text { Crude rate\% } \\
\text { Adjusted ratio }\end{array}$ & $\begin{array}{r}97 \\
6 \cdot 3 \\
95\end{array}$ & $\begin{array}{r}176 \\
6 \cdot 4 \\
114\end{array}$ & $\begin{array}{r}75 \\
7.3 \\
139\end{array}$ & $\begin{array}{r}350 \\
6 \cdot 6 \\
112\end{array}$ & 0.05 \\
\hline North Africa & $\begin{array}{l}\text { No. } \\
\text { Crude rate \% } \\
\text { Adjusted ratio }\end{array}$ & $\begin{array}{r}86 \\
4 \cdot 8 \\
71\end{array}$ & $\begin{array}{r}100 \\
4 \cdot 0 \\
72\end{array}$ & $\begin{array}{r}28 \\
3.8 \\
77\end{array}$ & $\begin{array}{r}214 \\
4 \cdot 2 \\
73\end{array}$ & ns \\
\hline Western countries & $\begin{array}{l}\text { No. } \\
\text { Crude rate \% } \\
\text { Adjusted ratio }\end{array}$ & $\begin{array}{r}57 \\
7 \cdot 0 \\
111\end{array}$ & $\begin{array}{r}72 \\
5 \cdot 1 \\
101\end{array}$ & $\begin{array}{r}37 \\
6 \cdot 9 \\
140\end{array}$ & $\begin{array}{r}166 \\
6 \cdot 0 \\
118\end{array}$ & 0.01 \\
\hline $\begin{array}{l}\text { Total (including } \\
\text { others) }\end{array}$ & $\begin{array}{l}\text { No. } \\
\text { Crude rate \% } \\
\text { Adjusted ratio }\end{array}$ & $\begin{array}{r}410 \\
5 \cdot 9 \\
91\end{array}$ & $\begin{array}{r}600 \\
5 \cdot 3 \\
98\end{array}$ & $\begin{array}{l}195 \\
6 \cdot 3 \\
127\end{array}$ & $\begin{array}{r}1,216 \\
5 \cdot 7 \\
100\end{array}$ & 0.001 \\
\hline
\end{tabular}


TABLE III

LOW BIRTH WEIGHT BY ETHNIC GROUP AND BIRTH ORDER (Ratios adjustod for maternal ase and education)

\begin{tabular}{|c|c|c|c|c|c|c|}
\hline \multirow{2}{*}{\multicolumn{2}{|c|}{$\begin{array}{l}\text { Birthplace of } \\
\text { Mother }\end{array}$}} & \multicolumn{4}{|c|}{ Birth Order } & \multirow{3}{*}{$\begin{array}{c}\begin{array}{c}\text { Total } \\
\text { (including unknowns) }\end{array} \\
\begin{array}{c}437 \\
5 \cdot 7 \\
111\end{array}\end{array}$} \\
\hline & & 1 & $2-3$ & $4-6$ & $7+$ & \\
\hline Israel & $\begin{array}{l}\text { No. } \\
\text { Crude rate \% } \\
\text { Adjusted ratio }\end{array}$ & $\begin{array}{l}196 \\
7 \cdot 7 \\
124\end{array}$ & $\begin{array}{r}165 \\
4 \cdot 8 \\
93\end{array}$ & $\begin{array}{r}57 \\
4 \cdot 8 \\
95\end{array}$ & $\begin{array}{r}17 \\
3 \cdot 7 \\
71\end{array}$ & \\
\hline Asia & $\begin{array}{l}\text { No. } \\
\text { Crude rate \% } \\
\text { Adjusted ratio }\end{array}$ & $\begin{array}{r}77 \\
7 \cdot 4 \\
134\end{array}$ & $\begin{array}{r}118 \\
7 \cdot 2 \\
123\end{array}$ & $\begin{array}{r}83 \\
5 \cdot 8 \\
108\end{array}$ & $\begin{array}{r}70 \\
5 \cdot 9 \\
106\end{array}$ & $\begin{array}{r}350 \\
6 \cdot 6 \\
118\end{array}$ \\
\hline North Africa & $\begin{array}{l}\text { No. } \\
\text { Crude rate \% } \\
\text { Adjusted ratio }\end{array}$ & $\begin{array}{r}51 \\
5 \cdot 3 \\
95\end{array}$ & $\begin{array}{r}71 \\
4 \cdot 5 \\
82\end{array}$ & $\begin{array}{r}47 \\
3.6 \\
68\end{array}$ & $\begin{array}{r}34 \\
3 \cdot 3 \\
61\end{array}$ & $\begin{array}{r}214 \\
4 \cdot 2 \\
78\end{array}$ \\
\hline Western countries & $\begin{array}{l}\text { No. } \\
\text { Crude rate \% } \\
\text { Adjusted ratio }\end{array}$ & $\begin{array}{r}70 \\
7 \cdot 7 \\
144\end{array}$ & $\begin{array}{r}66 \\
5 \cdot 6 \\
110\end{array}$ & $\begin{array}{r}23 \\
4 \cdot 7 \\
93\end{array}$ & $\begin{array}{r}7 \\
3 \cdot 6 \\
71\end{array}$ & $\begin{array}{r}166 \\
6 \cdot 0 \\
116\end{array}$ \\
\hline Total (including others) & $\begin{array}{l}\text { No. } \\
\text { Crude rate \% } \\
\text { Adjusted ratio }\end{array}$ & $\begin{array}{l}407 \\
7 \cdot 1 \\
132\end{array}$ & $\begin{array}{r}434 \\
5 \cdot 4 \\
102\end{array}$ & $\begin{array}{r}223 \\
4 \cdot 9 \\
93\end{array}$ & $\begin{array}{r}144 \\
4 \cdot 8 \\
88\end{array}$ & $\begin{array}{r}1,216 \\
5.7 \\
100\end{array}$ \\
\hline
\end{tabular}

western immigrant mothers occupy intermediate positions. When adjustment is made for differences in maternal age, birth order, and education, it is seen that there is a highly significant deficiency of low birth weight infants in the North African group and this is true at all levels of maternal age (Table II), birth order (Table III), and education. Between the remaining three groups of Asian, Israeli-born, and western immigrant mothers there are no significant differences, either in total low birth weight ratios or at any level of maternal age, education or birth order.

\section{Maternal Age}

Older mothers are at special risk (Table I). The crude rate of low birthweight is highest $(6.3 \%)$ at age 35 and over and lowest (5.0) at age 30-34. Crude rates for mothers aged 40 and over and for young mothers aged less than 20 were also examined and were higher than in the adjacent age-groups. When adjustment is made for ethnic group, birth order, and maternal education, the ratio for the older mothers shows a highly significant excess compared with that for the mothers of other ages.

The extent of the maternal age effect differs between the ethnic groups (Table II). In the Israeliborn and western immigrant groups the excess of underweight infants in older mothers is highly significant; in Asian immigrants it is of low significance, and in the North African immigrant group it is not significant. These ethnic differences in the extent of the maternal age effect are not in themselves significant at the $5 \%$ level.

TABLE IV

LOW BIRTH WEIGHT BY MATERNAL AGE AND BIRTH ORDER (Ratios adjusted for ethnic group and education)

\begin{tabular}{|c|c|c|c|c|c|}
\hline \multirow{2}{*}{ Birth Order } & & \multicolumn{3}{|c|}{ Age of Mother (yr.) } & \multirow{2}{*}{$\begin{array}{l}\text { Total } \\
\text { (including unknowns) }\end{array}$} \\
\hline & & 24 or less & $25-34$ & 35 or more & \\
\hline 1 & $\begin{array}{l}\text { No. } \\
\text { Crude rate \% } \\
\text { Adjusted ratio }\end{array}$ & $\begin{array}{r}255 \\
6 \cdot 6 \\
110\end{array}$ & $\begin{array}{r}140 \\
8 \cdot 2 \\
140\end{array}$ & $\begin{array}{r}11 \\
9 \cdot 3 \\
167\end{array}$ & $\begin{array}{r}407 \\
7 \cdot 1 \\
130\end{array}$ \\
\hline $2-3$ & $\begin{array}{l}\text { No. } \\
\text { Crude rate \% } \\
\text { Adjusted ratio }\end{array}$ & $\begin{array}{r}137 \\
5 \cdot 3 \\
94\end{array}$ & $\begin{array}{r}244 \\
5 \cdot 1 \\
93\end{array}$ & $\begin{array}{r}47 \\
8 \cdot 0 \\
142\end{array}$ & $\begin{array}{r}434 \\
5 \cdot 4 \\
98\end{array}$ \\
\hline $4-6$ & $\begin{array}{l}\text { No. } \\
\text { Crude rate \% } \\
\text { Adjusted ratio }\end{array}$ & $\begin{array}{r}17 \\
4 \cdot 3 \\
71\end{array}$ & $\begin{array}{r}152 \\
4 \cdot 6 \\
79\end{array}$ & $\begin{array}{r}54 \\
6 \cdot 1 \\
91\end{array}$ & $\begin{array}{r}223 \\
4 \cdot 9 \\
83\end{array}$ \\
\hline 7 or more & $\begin{array}{l}\text { No. } \\
\text { Crude rate \% } \\
\text { Adjusted ratio }\end{array}$ & $\begin{array}{r}1 \\
14 \cdot 3 \\
200\end{array}$ & $\begin{array}{r}60 \\
4 \cdot 0 \\
66\end{array}$ & $\begin{array}{r}80 \\
5 \cdot 3 \\
87\end{array}$ & $\begin{array}{r}144 \\
4 \cdot 8 \\
78\end{array}$ \\
\hline Total (including unknowns) & $\begin{array}{l}\text { No. } \\
\text { Crude rate \% } \\
\text { Adjusted ratio }\end{array}$ & $\begin{array}{r}410 \\
5.9 \\
107\end{array}$ & $\begin{array}{l}600 \\
5 \cdot 3 \\
94\end{array}$ & $\begin{array}{r}195 \\
6 \cdot 3 \\
102\end{array}$ & $\begin{array}{r}1,216 \\
5 \cdot 7 \\
100\end{array}$ \\
\hline
\end{tabular}


TABLE V

LOW BIRTH WEIGHT BY MATERNAL AGE AND EDUCATION (Ratios adjusted for birth order and ethnic group)

\begin{tabular}{|c|c|c|c|c|c|}
\hline & & \multicolumn{3}{|c|}{ Age of Mother (yr.) } & \multirow{2}{*}{$\begin{array}{c}\text { Total } \\
\text { (including unknowns) }\end{array}$} \\
\hline \multicolumn{2}{|c|}{ Years of Maternal Schooling } & 24 or less & $25-34$ & 35 or more & \\
\hline $\begin{array}{l}13+ \\
\text { and } \\
9-12\end{array}$ & $\begin{array}{l}\text { No. } \\
\text { Crude rate \% } \\
\text { Adjusted ratio }\end{array}$ & $\begin{array}{r}161 \\
5 \cdot 0 \\
76\end{array}$ & $\begin{array}{r}226 \\
5.0 \\
88\end{array}$ & $\begin{array}{r}41 \\
5 \cdot 6 \\
107\end{array}$ & $\begin{array}{r}428 \\
5 \cdot 0 \\
85\end{array}$ \\
\hline $\begin{array}{l}5-8 \\
\text { and } \\
0-4\end{array}$ & $\begin{array}{l}\text { No. } \\
\text { Crude rate \% } \\
\text { Adjusted ratio }\end{array}$ & $\begin{array}{r}156 \\
6.1 \\
103\end{array}$ & $\begin{array}{r}250 \\
5 \cdot 1 \\
101\end{array}$ & $\begin{array}{r}94 \\
5 \cdot 4 \\
114\end{array}$ & $\begin{array}{r}503 \\
5 \cdot 4 \\
104\end{array}$ \\
\hline Unknown & $\begin{array}{l}\text { No. } \\
\text { Crude rate \% } \\
\text { Adjusted ratio }\end{array}$ & $\begin{array}{r}93 \\
8 \cdot 3 \\
116\end{array}$ & $\begin{array}{r}124 \\
6 \cdot 9 \\
113\end{array}$ & $\begin{array}{r}60 \\
9 \cdot 8 \\
161\end{array}$ & $\begin{array}{r}285 \\
8 \cdot 8 \\
119\end{array}$ \\
\hline Total & $\begin{array}{l}\text { No. } \\
\text { Crude rate \% } \\
\text { Adjusted ratio }\end{array}$ & $\begin{array}{r}410 \\
5 \cdot 9 \\
92\end{array}$ & $\begin{array}{r}600 \\
5 \cdot 3 \\
97\end{array}$ & $\begin{array}{r}195 \\
6 \cdot 3 \\
123\end{array}$ & $\begin{array}{r}1,216 \\
5 \cdot 7 \\
100\end{array}$ \\
\hline
\end{tabular}

\section{BIRTH ORDER}

First-born infants are most at risk for low birth weight with a crude rate of $7 \cdot 1 \%$ (Table I). There are further significant falls in adjusted ratios between each of the subsequent birth order groups. This tendency to decreasing risk of low birth weight with increasing birth order is seen within each ethnic and education group and in all age-groups with the exception of those under 25.

\section{MATERnal Education}

Crude education differentials are small, rates ranging from $5.0 \%$ in the groups with $13+$ and 9-12 years of education to $5.7 \%$ in the $0-4$ years group (Table I). After adjustment for ethnic group, maternal age, and birth order these differentials are much larger and the ratios decrease progressively with increasing years of education.

Adjusted education differentials are greater in younger than in older women (Table V), and are of greater significance in first births than in second and third births (Table VI). There is no significant education effect in fourth and subsequent births.

Firstborn infants of mothers in the 13+ education group (university or professionally educated women) are more likely to have a low birth weight than the firstborn of mothers with 9-12 years of education (who attended or completed high-school) but the difference is not significant in this population (Table VI).

TABle VI

LOW BIRTH WEIGHT BY BIRTH ORDER AND MATERNAL EDUCATION (Ratios adjusted for ethnic group and maternal age)

\begin{tabular}{|c|c|c|c|c|c|c|}
\hline & & \multicolumn{4}{|c|}{ Birth Order } & \multirow{2}{*}{$\begin{array}{c}\text { Total } \\
\text { (including unknowns) } \\
\end{array}$} \\
\hline \multicolumn{2}{|c|}{ Years of Maternal Schooling } & 1 & $2-3$ & $4-6$ & $7+$ & \\
\hline $13+$ & $\begin{array}{l}\text { No. } \\
\text { Crude rate \% } \\
\text { Adjusted ratio }\end{array}$ & $\begin{array}{r}99 \\
6 \cdot 7 \\
116\end{array}$ & $\begin{array}{r}58 \\
3 \cdot 9 \\
71\end{array}$ & $\begin{array}{r}6 \\
2 \cdot 1 \\
38\end{array}$ & $\begin{array}{r}2 \\
5 \cdot 1 \\
91\end{array}$ & $\begin{array}{r}165 \\
5 \cdot 0 \\
89\end{array}$ \\
\hline $9-12$ & $\begin{array}{l}\text { No. } \\
\text { Crude rate \% } \\
\text { Adjusted ratio }\end{array}$ & $\begin{array}{r}119 \\
5 \cdot 8 \\
99\end{array}$ & $\begin{array}{r}114 \\
4 \cdot 6 \\
82\end{array}$ & $\begin{array}{r}28 \\
50 \\
91\end{array}$ & $\begin{array}{r}2 \\
2 \cdot 0 \\
35\end{array}$ & $\begin{array}{r}263 \\
500 \\
89\end{array}$ \\
\hline $5-8$ & $\begin{array}{l}\text { No. } \\
\text { Crude rate \% } \\
\text { Adjusted ratio }\end{array}$ & $\begin{array}{r}97 \\
7.6 \\
133\end{array}$ & $\begin{array}{r}128 \\
5 \cdot 7 \\
102\end{array}$ & $\begin{array}{r}56 \\
3 \cdot 7 \\
68\end{array}$ & $\begin{array}{r}20 \\
3 \cdot 4 \\
63\end{array}$ & $\begin{array}{r}301 \\
5 \cdot 3 \\
96\end{array}$ \\
\hline $0-4$ & $\begin{array}{l}\text { No. } \\
\text { Crude rate \% } \\
\text { Adjusted ratio }\end{array}$ & $\begin{array}{r}22 \\
9 \cdot 7 \\
183\end{array}$ & $\begin{array}{r}48 \\
7 \cdot 1 \\
130\end{array}$ & $\begin{array}{r}60 \\
4.9 \\
91\end{array}$ & $\begin{array}{r}70 \\
4 \cdot 9 \\
91\end{array}$ & $\begin{array}{r}202 \\
5 \cdot 7 \\
105\end{array}$ \\
\hline Unknown & $\begin{array}{l}\text { No. } \\
\text { Crude rate \% } \\
\text { Adjusted ratio }\end{array}$ & $\begin{array}{r}70 \\
10.2 \\
189\end{array}$ & $\begin{array}{r}86 \\
8 \cdot 1 \\
158\end{array}$ & $\begin{array}{r}73 \\
7 \cdot 5 \\
154\end{array}$ & $\begin{array}{r}50 \\
60 \\
126\end{array}$ & $\begin{array}{r}285 \\
8 \cdot 8 \\
160 \\
\end{array}$ \\
\hline Total & $\begin{array}{l}\text { No. } \\
\text { Crude rate \% } \\
\text { Adjusted ratio }\end{array}$ & $\begin{array}{r}407 \\
7 \cdot 1 \\
124\end{array}$ & $\begin{array}{r}434 \\
5 \cdot 4 \\
99\end{array}$ & $\begin{array}{r}223 \\
4 \cdot 9 \\
92 \\
\end{array}$ & $\begin{array}{r}144 \\
48 \\
92 \\
\end{array}$ & $\begin{array}{r}1,216 \\
5 \cdot 7 \\
100\end{array}$ \\
\hline $\begin{array}{l}\text { Significance of adjusted } \\
\text { unknowns) }\end{array}$ & differences (excluding & $p<0.0001$ & $p<0-01$ & 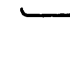 & & $p<0.00001$ \\
\hline
\end{tabular}


TABLE VII

LOW BIRTH WEIGHT BY ETHNIC GROUP AND MATERNAL EDUCATION

(Ratios adjusted for maternal age and birth order within each ethnic group)

\begin{tabular}{|c|c|c|c|c|}
\hline \multirow{2}{*}{\multicolumn{2}{|c|}{ Years of Maternal Schooling }} & \multicolumn{2}{|c|}{ Birthplace of Mother } & \multirow{3}{*}{$\begin{array}{c}\begin{array}{c}\text { Total } \\
\text { (including others) }\end{array} \\
\begin{array}{c}165 \\
5 \cdot 0 \\
79\end{array}\end{array}$} \\
\hline & & \multirow{2}{*}{$\begin{array}{c}\begin{array}{c}\text { Asia and } \\
\text { North Africa }\end{array} \\
\begin{array}{c}11 \\
4 \cdot 1 \\
67\end{array}\end{array}$} & \multirow{2}{*}{$\begin{array}{c}\begin{array}{c}\text { Israel and } \\
\text { Western Countries }\end{array} \\
\begin{array}{c}154 \\
5 \cdot 1 \\
81\end{array}\end{array}$} & \\
\hline $13+$ & $\begin{array}{l}\text { No. } \\
\text { Crude rate \% } \\
\text { Adjusted ratio }\end{array}$ & & & \\
\hline $9-12$ & $\begin{array}{l}\text { No. } \\
\text { Crude rate \% } \\
\text { Adjusted ratio }\end{array}$ & $\begin{array}{r}68 \\
4 \cdot 2 \\
73\end{array}$ & $\begin{array}{r}194 \\
5 \cdot 4 \\
92\end{array}$ & $\begin{array}{r}263 \\
5 \cdot 0 \\
82\end{array}$ \\
\hline $5-8$ & $\begin{array}{l}\text { No. } \\
\text { Crude rate \% } \\
\text { Adjusted ratio }\end{array}$ & $\begin{array}{r}172 \\
5 \cdot 2 \\
96\end{array}$ & $\begin{array}{l}128 \\
5.4 \\
103\end{array}$ & $\begin{array}{r}301 \\
5 \cdot 3 \\
96\end{array}$ \\
\hline 0.4 & $\begin{array}{l}\text { No. } \\
\text { Crude rate \% } \\
\text { Adjusted ratio }\end{array}$ & $\begin{array}{l}169 \\
5 \cdot 3 \\
100\end{array}$ & $\begin{array}{r}23 \\
8 \cdot 4 \\
170\end{array}$ & $\begin{array}{r}202 \\
5.7 \\
114\end{array}$ \\
\hline Unknown & $\begin{array}{l}\text { No. } \\
\text { Crude rate \% } \\
\text { Adjusted ratio }\end{array}$ & $\begin{array}{r}144 \\
7 \cdot 3 \\
134\end{array}$ & $\begin{array}{l}104 \\
8.5 \\
156\end{array}$ & $\begin{array}{l}285 \\
8 \cdot 8 \\
135\end{array}$ \\
\hline Total & $\begin{array}{l}\text { No. } \\
\text { Crude rate \% } \\
\text { Adjusted ratio }\end{array}$ & $\begin{array}{l}564 \\
5 \cdot 5 \\
100\end{array}$ & $\begin{array}{l}603 \\
5 \cdot 8 \\
100\end{array}$ & $\begin{array}{r}1,216 \\
5.7 \\
100\end{array}$ \\
\hline \multicolumn{2}{|c|}{$\begin{array}{l}\text { Significance of adjusted education differences (excluding } \\
\text { unknowns) }\end{array}$} & 0.02 & 0.00001 & 0.00001 \\
\hline
\end{tabular}

There are ethnic differences in the extent of the maternal education effect on low birth weight (Table VII). In the Asian and North African immigrant mothers education is of low significance in contrast to the Israeli-born and western immigrant groups. In the latter there are especially high rates and ratios of underweight babies in mothers with 0-4 years of schooling.

\section{Discussion}

The overall low birth weight rate of $5.7 \%(6.4 \%$ if the births recorded as exactly $2,500 \mathrm{~g}$. are included) is very similar to those of Britain and the U.S.A. (Butler and Bonham, 1963; Shapiro et al., 1968) and to the figures reported in previous Israeli studies (Halevi, 1959).

The observation that immigrants from North African countries have fewer underweight babies confirms a previous report by Rosenbluth (1968) of higher mean birth weights for this group and suggests that a genetic factor may be involved. The finding has yet to be related to such factors as maternal height and period of gestation, of which we have little information.

It is surprising that there are no apparent differences between the Asian, western, and Israeli-born groups. Asian and European Jews have been separate for many generations and show marked anthropological differences, being culturally and genetically much closer to the gentile populations among whom they have been living than they are to each other (Patai, 1953; Goldschmidt, 1963).
Future research, when larger numbers of births are available for study, may show differences between the immigrants from individual countries: for instance, Jews from Turkey, the Balkans, south Europe, and Holland include a high proportion of descendants of Jews expelled from Spain in 1492, with cultural and genetic affinities to North African Jews. Yemenites, on the other hand, were separate for about 2,500 years, with relatively little contact with other Jews (Patai, 1953).

A measure of the health status of immigrants from Asia and Africa before their arrival in Israel is given by Schmelz (1965), who reports child death rates ( $0-4$ years) of 200-500 per thousand livebirths. These figures reflect the poverty, malnutrition, and ill-health suffered by immigrants in the past and are substantiated by government statistics and by many studies of health, nutrition, and diet (reviewed in Prywes, 1960). In spite of the adverse environmental experience of these immigrant mothers in the past, they do not have more underweight babies in the present. There is no evidence from this study that our mothers, as a population, have suffered any appreciable damage to their reproductive ability, such as that suggested by Thomson and Baird for women of the lower social classes in Britain. On the contrary, low birth weight and perinatal and infant death rates are low (Legg, Davies, Prywes, Sterk, and Weiskopf, 1969) although fertility is high (Rabi, 1968). Furthermore, low birth weight is rarest in the North Africans, who, as a group, immigrated most recently, many having arrived 
since 1961 (Rabi, 1968). These findings suggest that a mother's present health status is of far greater importance for the outcome of her pregnancy (at least in so far as low birth weight is concerned) than her past environmental experience.

The importance of genetic factors in the social class differentials in Britain may be underestimated. Thomson (1959) has shown how upward and downward social mobility is linked to differences in maternal intelligence, height, and reproductive performance. Baird (1962) has suggested that a continuous process of genetic selection might lead to a perpetuation of social-class differentials in pregnancy outcome, and our data (Table VII) would support this hypothesis. The effect of education on low birth weight is of least significance in immigrants from Asia and North Africa, in whom the level of education actually achieved by a mother was largely a matter of chance, depending on her age at immigration. In the western immigrants and Israeli-born women (a large proportion of whom are also of western origin), the level of education achieved by each woman is probably a closer reflection of her health and intellectual ability, and may be based on several generations of selection: education-differences in low birth weight in these women are of greater significance.

\section{SUMmary AND CoNClusions}

In a study of all singleton infants born in West Jerusalem to local residents whose pregnancies had lasted 28 weeks or longer, 1,216 infants weighed less than 2,500 g., a rate of $5 \cdot 7 \%$

Between the different ethnic groups of Jews, low birth weight was rarest $(4.2 \%)$ in the infants of mothers who had immigrated from North Africa. This rarity was seen at all levels of maternal age, birth order, and education, and after adjustment for these three variables the ratio was significantly lower at the $0.001 \%$ level than those for infants of other groups. There were no significant differences between the adjusted low birth weight ratios of the infants born to the other ethnic groups, i.e., Israeliborn mothers or immigrants from Asian or western countries.

Infants of mothers aged 35 or more were more at risk of low birth weight than infants of younger mothers. The effect, after adjustment for maternal education and birth order, was highly significant in the infants of Israeli-born and western mothers, of low significance in the infants of immigrants from Asia, and not significant in the North African group.

First-born infants were most at risk and there were further significant decreases in low birth weight frequency between each of the subsequent birth order groups. This pattern was seen in all ethnic groups, education ranks, and all age-groups of mothers aged 25 or more.

Low birth weight decreased significantly with increasing education, although before adjustment for ethnic group, maternal age, and birth order, differentials were very small. Education differences were of greater significance in the Israeli-born and western immigrant mothers than in the group who had immigrated from countries of Asia and North Africa.

There is no evidence that the poverty, malnutrition and ill-health suffered by some immigrant groups in their childhood has an adverse effect on the present levels of low birth weight.

Thanks are due to E. Peritz, Ph.D., and to $M$. Haber, M.Sc., for statistical advice and to B. Tzur, M.Sc., of Yael Management Automation Ltd., for computing services.

The study was supported by research grants from the Children's Bureau and National Institutes of Health, U.S. Department of Health, Education and Welfare.

This is the fourth paper from the Jerusalem Perinatal Study.

\section{REFERENCES}

Abramowicz, M., and Kass, E. H. (1966). Pathogenesis and prognosis of prematurity. New Engl. J. Med., 275, 878, 938, 1001.

BAIRD, D. (1962). Environmental and obstetrical factors in prematurity, with special reference to experience in Aberdeen. Bull. Wld Hlth Org., 26, 291.

—, and IllsLeY, R. (1953). Environment and childbearing. Proc. roy. Soc. Med., 46, 53.

Butler, N. R., and Alberman, E. D. (1969). Perinatal Problems: The Second Report of the 1958 British Perinatal Mortality Survey. Livingstone, Edinburgh. - and Bonham, D. G. (1963). Perinatal Mortality: The First Report of the 1958 British Perinatal Mortality Survey. Livingstone, Edinburgh.

Central Bureau of Statistics (1952-69). Causes of Death, 1950-67. Jerusalem, Israel.

- (1958-68). Diagnostic Statistics of Hospitalized Patients 1957-66 and Statistics of Hospitalization, 1950-56. Jerusalem, Israel.

- (1951-69). Statistical Abstracts of Israel, 1950-69. Jerusalem, Israel.

Davies, A. M., Prywes, R., Tzur, B., Weiskopf, P., and STERK, V. V. (1969). The Jerusalem Perinatal Study. 1. Design and organization of a continuing, community based, record-linked survey. Israel J. med. Sci., 5, 1095.

—, Tzur, B., Prywes, R., and Weiskopf, P. (1968). The Jerusalem Perinatal Study. Methodology Manual. Department of Medical Ecology, Hebrew University of Jerusalem. 
EISENSTADT, S. N. (1967). Israeli Society. Weidenfeld and Nicholson, London.

ELINER, D. (1968). The absorption of immigrants. In Health Services in Israel. Edited by T. Grushka, pp. 409-417. Ministry of Health, Jerusalem.

VAN Elteren, P. (1960). On the combination of independent two sample tests of Wilcoxon. Bull. Inst. int. Stat., 37, 3e livraison, p. 351.

Goldschmid, E. (Ed.) (1963). The Genetics of Migrant and Isolate Populations: Proceedings of a Conference on Human Population Genetics in Israel, held at the Hebrew University. Williams and Wilkins, Baltimore.

Goodman, L. A. (1964). Simultaneous confidence limits for cross-product ratios in contingency tables. $J$. roy Stat. Soc. B., 26, 86.

Halevi, H. S. (1959). Some statistical aspects of prematurity in Israel. Harefuah, 56, 201.

HuPPERT, E. L. (1968). Health statistics. In Health Services in Israel, Edited by T. Grushka, pp. 341-351. Ministry of Health, Jerusalem.

Kark, S. L., Peritz, E., Shiloh, A., and Slome, C. (1964). Epidemiological analysis of the hemoglobin picture in parturient women of Jerusalem. Amer. J. publ. Hlth, 54, 947.

Legg, S., Davies, A. M., Prywes, R., Sterk, V. V., and Weiskopf, P. (1969). The Jerusalem Perinatal Study. 2. Infant Deaths 1964-66: a Cohort study of socioethnic factors in deaths from congenital malformations and from environmental and other causes. Israel J. med. Sci., 5, 1107.
Mantel, N., and Haenszel, W. (1959). Statistical aspects of the analysis of data from retrospective studies of disease. J. nat. Cancer Inst., 22, 719.

PATAI, R. (1953). Israel Between East and West. Jewish Publication Society of America, Philadelphia.

PryWes, M. (1960). Medical and Biological Research in Israel. Grune and Stratton, New York.

RABI, Z. (1968). A demographic assay. In Health Services in Israel, Edited by T. Grushka, pp. 352-391. Ministry of Health, Jerusalem.

Rantakallio, P. (1969). Groups at Risk in Low Birth Weight Infants and Perinatal Mortality. Department of Pediatrics, University of Oulu, Finland.

RosenbluTH, S. (1968). The influence of sex, age, immigration period, country of birth and parity on birth weights: a survey of 7,980 birth certificates. M.P.H. Thesis, Department of Social Medicine, Hebrew University of Jerusalem.

Schmelz, O. (1965). Reduction of child mortality of new immigrants in Israel. Paper presented to the World Population Conference, Belgrade (Mimeo).

ShapIro, S., Schlesinger, E. R., and NesbitT, R. E. L. Jr. (1968). Infant, Perinatal, Maternal, and Childhood Mortality in the United States. Harvard University Press, Cambridge, Massachusetts.

Thomson, A. M. (1959). Maternal stature and reproductive efficiency. Eugen Rev., 51, 157.

- and BILlewicz, W. Z. (1963). Nutritional status, maternal physique and reproductive efficiency. Proc. Nutr. Soc., 22, 55. 